\title{
The impact of irrigated rice on the transmission of schistosomiasis and geohelminthiasis in Niakaramandougou, Côte d'Ivoire
}

\author{
Grégoire Yapi YAPI ${ }^{1 *}$, Mahama TOURÉ ${ }^{2}$, Moussa Dieng SARR ${ }^{3}, \mathrm{~N}^{\prime}$ takpé ABO ${ }^{1}$ and \\ Salia DIABATÉ ${ }^{1}$ \\ ${ }^{I}$ Veterinary and Medical Entomology Centre (CEMV), \\ University Alassane Ouattara of Bouake', 27 BP 529 Abidjan 27, Côte d'Ivoire. \\ ${ }^{2} J e a n$ Lourougnon Guédé University (UJLG), BP 150 Daloa, Côte d'Ivoire. \\ ${ }^{3}$ National Health Service, Senegal, Phone number (+221) 775337824 \\ *Corresponding author; E-mail: yapigrec@yahoo.fr; 27 BP 529 Abidjan 27, Côte d'Ivoire. \\ Tel.: +225224142 51; Fax: +22522415722
}

\begin{abstract}
The prevalence and intensity of the infection caused by schistosomiasis and geohelmintiasis were studied in relation to irrigated rice cultivation in Côte d'Ivoire. In a cross-sectional study conducted on schistosomiasis in Niakaramandougou, in the savannah (North) area of Côte d'Ivoire, from April to September 2001, the potential importance of soil-transmitted helminth infections was assessed. Villages were classified according to the surrounding inland valleys into two agro-ecosystems: (R2) full or partial water control allowing two rice cycles per year and (R0), the absence of rice growing. Urine and stool samples were collected from children in two villages in the savannah zone. Three hundred and fifty-three (353) children aged 4 to 15 years were examined, of whom 220 were from Kafiné village (R2) and 133 from Pékaha village (R0). The prevalence of Schistosoma haematobium was $10 \%$, and $2.3 \%$ in R2 and R0 respectively. S. mansoni prevalence was $29.1 \%$ in R2 and $31.6 \%$ in R0. Ascariasis lumbricoides (12.3\%) and Trichuris trichuira were the only species present in the two agro-ecosystems. Prevalences of $S$. haematobium adjusted for the effects on the villages were significantly different in the two agro-ecosystems. In savannah rice growing villages, negative binomial regression on the intensity of the infection of $S$. haematobium showed significant positive relations with the surface of rice cultivated inland valleys, whereas uncultivated inland valleys showed no significant relation. However, S. mansoni infection intensity showed significant negative relations with infection intensity of each agro-ecosystem.

(C) 2017 International Formulae Group. All rights reserved.
\end{abstract}

Keywords: Rice; Irrigation; Schistosomiasis; S. mansoni; S. haematobium; Agro-ecosystem; Côte d'Ivoire.

\section{INTRODUCTION}

In West Africa, Schistosoma haematobium and Schistosoma mansoni are widespread human parasites, which have Bulinus and Biomphalaria snails as their intermediate hosts, respectively. Both
Biomphalaria and Bulinus snails occur mainly in vegetation-rich canals and lakes, whereas they are rarely found in rice fields. The increase in $S$. haematobium prevalence after the construction of large dams (for hydroelectric power generation and/or irrigation) 
in West Africa is well documented (Steinman et al., 2006; Matthy et al., 2007). Parallel increase in S. mansoni prevalence has also been observed. There is evidence in Ghana, Mali, Burkina Faso and Senegal that both the prevalence and the intensity of schistosomiasis infection are generally high in large-scale irrigation schemes with or without rice cultivation (Bouguerra, 2001; Sturrock et al., 2001; Coulibaly et al., 2004). However, the introduction of such a scheme may not necessarily increase the prevalence of schistosomiasis, as in some studies it remained low or was already high before implementation (Audibert et al., 2001; Barboza et al., 2012). Outside large-scale irrigation schemes, many studies compared rice-cultivating villages with non-ricecultivating villages. Generally, prevalence varies considerably among villages both within and outside rice growing areas. In Guinea savannah and Sudan savannah zones of West Africa, numerous small dams have been constructed to provide water for irrigation and pastoral purposes. Despite strong evidence of a negative impact of these dams on urinary schistosomiasis based on a study in Ghana and one in the Dogon country of Mali, other studies in Ghana, Cameroon, Nigeria and Burkina Faso have not found any evidence (Tchuem-Tchuenté, 2006) The World Health Organisation estimated that more than one billion of the world's population is chronically affected by soil-transmitted helminth infections, which are lightly correlated with poverty, poor environmental hygiene and impoverished health services. Intestinal helminthiasis are among the most common communicable diseases of school-age children in certain communities and tend to occur at highest intensity in this age group (Scolari et al., 2000; Dabo et al., 2003). There is strong evidence to support the relationship between helminth infections, malnutrition and child development, leading to negative 1401 consequences for cognitive function and learning ability (Diouf et al., 2000). Epidemiological surveys carried out in Côte d'Ivoire showed a large regional variation in intestinal helminths prevalence (Matthys et al., 2007).

In Côte d'Ivoire, initiated by the government and donors in the seventies to meet the demand for food, many small rice projects in inland valleys were exploited both in the (Guinea) savannah and forest zones. The Veterinary and Medical Entomology Center (CEMV) was set up to study potential impacts of rice production intensification methods on human health. Within this framework, a cross-sectional study was carried out between April and September 2001 to assess the impact of irrigated rice growing on schistosomiasis transmission in the savannah zone of Côte d'Ivoire, and to characterize the level of prevalence and intensity of schistosomiasis infection and other helminth infections in that zone.

\section{MATERIALS AND METHODS}

The study was carried out in Niakaramandougou $\left(8^{\circ} 40-8^{\circ} 48 \mathrm{~N}\right.$ and $5^{\circ} 17$ $5^{\circ} 18 \mathrm{~W}$ ), in the savannah zone in the North of Côte d'Ivoire, where the population density is 20-40 inhabitants per $\mathrm{Km}^{2}$ (Figure 1). The study area has two main seasons: a dry season from November to April, and a rainy season from May to October. Kafiné village is situated at $18 \mathrm{Km}$ from Niakaramandougou. It is specialised in the production of irrigated rice through a Rice Centre Project inititated in the area in 1991. Diallo's work (1996) showed that from 1991 (the date of the implementation of the project) until 1996, the rice perimeter, the study area, was unscathed of schistosomiasis. The village had a school of six classrooms and a hand pump drilling system constructed in 1979. In the health field, Kafiné benefited from the implementation of a Malaria Research 
Program conducted by Pierre Richet Institut (IPR) of Bouaké (Côte d'Ivoire) that promoted the use of insecticide-treated nets. The pilot village Pékaha, is located at $09 \mathrm{Km}$ away from Kafiné, along the same road. The village had a school of three classrooms. It has no inland valleys and does not practice irrigated rice growing. Its hydrography is constituted of three rivers that dry up in the dry season.

We assigned both villages (Kafiné and Pékaha) to two different agro-ecosystem classes according to the surrounding inland valleys within a $2 \mathrm{Km}$ radius: (R0) villages with inland valleys without rice cultivation and (R2) villages with inland valleys with partial or full water control that permits two or more cycles of rice cropping per year. Many studies have shown that children aged between 4 and 15 years are particularly at risk because they are attracted by water and pass the greatest number of parasite eggs (Yapi, 2008; Tandina et al., 2016). Urine and stool samples were therefore collected in school age (4-15 years) children of in both villages: Kafiné (R2) and Pékaha (R0). Urine filtration technique was used on a single $10 \mathrm{~mL}$ sample, and egg counts of $S$. haematobium were expressed as eggs/10 $\mathrm{mL}$ of urine. Schistosoma mansoni and other intestinal parasites (Yapi, 2008) were screened by the Kato-Katz method and the egg counts were expressed per gram of faeces. All Schistosoma infected children were treated free with a single oral dose of praziquantel $(40 \mathrm{mg} / \mathrm{kg}$ of body weight) and with Mebendazole for children infected by Soil Transmitted Helminthiasis (STH).

\section{Statistical analysis}

The Data were entered and verified using EpiInfo v6.04 software (Centers for Disease Control and Prevention, Atlanta, Georgia, USA), and statistical analysis was carried out in Stata v6.0 software (Stata Corp., Collage, TX, USA). Logistic regression was applied to assess the effect of agro-ecosystem class on the prevalence of infection. The variation between the two villages within both agro- ecosystems was accounted for by including random effects at each village level. The logistic models were adjusted for age and sex. The likelihood ratio test (LRT) was used to assess significance of associations (Mitchell and Pagano, 2012).

Negative binomial regression models were applied to analyze the intensity of infection (Chang, 2005; Minami et al., 2007). The distribution of parasites is highly aggregated since most individuals have few parasites and few have a high parasite burden. This implies that the variation in the parasite load between individuals is expected to be higher than the average parasite load. A separate negative binomial model was fitted for each village and system and dispersion analysis was carried out to assess whether there was significant variation in the degree of aggregation between villages within each system. Likelihood ratio test was used to test for over-dispersion (Ridout et al,, 2001). Negative binomial regressions were then applied to assess the effects of agroecosystems on the intensity of infection using a separate aggregation parameter for each village. The negative binomial models were adjusted for age and sex. 


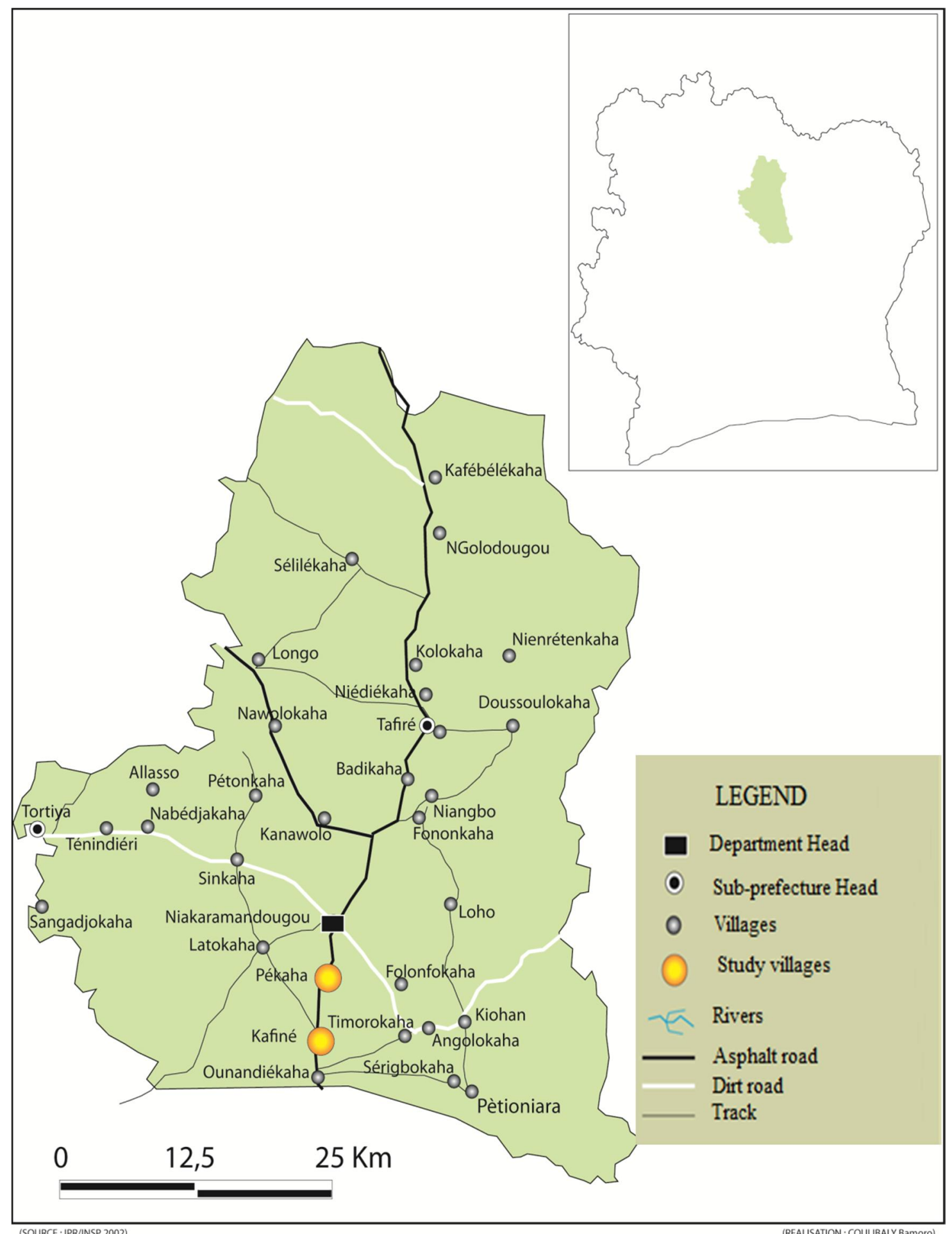

Figure 1: Presentation of the study area, Northern of Côte d'Ivoire. 
RESULTS

Kafiné village (Agro-ecosystem R2)

The overall prevalence of $S$. haematobium infection was $10 \%$. It was $3.2 \%$ for girls and $6.8 \%$ for boys. The infection prevalence of $1.8 \%, 4.6 \%$ and $3.6 \%$ are obtained respectively in children aged 4-7 years, 8-11 years and 12-15 years. The Bivariate analysis (Table 1) indicated that statistically significant associations of S. haematobium prevalence with only $12-15$ year-old children were more infected than children less than 8 years old $(95 \% \mathrm{CI}=1.50$ 18.84 and $\mathrm{P}=0.0254$ ). Boys and girls were identically infected $(95 \% \mathrm{CI}=8.87-5.71$ and $\mathrm{P}=0.084$ ). The bivariate analysis of the egg loads (Table 1) gave similar results to those with the prevalence.

The prevalence of $S$. mansoni was 29.1\% (Table 2). Bivariate analysis indicated statistically no significant associations between S. mansoni infection and age and sex (Table $2)$. The geometric average egg load was low (3.1 eggs/g stools). Negative binomial regression with egg load data indicated that girls had strong ovular load than boys $(\mathrm{IRR}=0.63 ; 95 \% \quad \mathrm{CI}=0.43-0.93 \quad$ and $\mathrm{P}=0.0187$ ).

\section{Pékaha village (Agro-ecosystem R0)}

The global prevalence of $S$. haematobium was $2.3 \%$ (Table 3 ). Given the low rate of patients, no statistical analysis could be made.

The prevalence of $S$. mansoni was $31.6 \%$ with $18.1 \%$ of girls and $13.5 \%$ of boys
(Table 3). The statistical analysis indicated that girls were more infected than boys $(\mathrm{OR}=0.4 ; 95 \% \mathrm{CI}=0.20-0.90$ and $\mathrm{P}=0.0240)$. The difference of infection between age groups was not significant. The average parasite load was $3.5 \mathrm{eggs} / \mathrm{g}$ stools. The Negative binomial regression with egg loads showed similar relations of $S$. mansoni infection to gender as the analysis with prevalence.

\section{Comparison of Agro-ecosystems R2 and R0}

The other intestinal parasites found in Kafiné (R2) village were Ascaris lumbricoides and Trichuris trichuira with respectively $12.3 \%$ and $2.7 \%$ of prevalence infection. The geometric egg load was low for the two worms. In Pékaha (R0), the ascariasis and trichuriasis were existing infections. There is no significant difference of infection related to age and gender (Table 4).

After adjusting for age and gender, prevalence of $S$. haematobium infection was significantly higher in R2 (Kafiné village) than in R0 (Pékaha village) (OR (R2vs.R0) $=0.2 ; 95 \% \mathrm{CI}=0.06-0.71$ and $\mathrm{P}=0.0354$ ) (Table 5).

Geometric average egg loads gave similar results to the prevalence of infection (Table 6). Those results indicated significant influence of irrigated rice growing on the transmission of urinary schistosomiasis in savannah areas (Niakaramandougou). Intestinal schistosomiasis showed no significant relation between irrigated rice lowlands. 
Table 1: Logistic regression model with random effect to account association between schistosomiasis infection with age and sex in Kafiné (Niakaramandougou, Côte d'Ivoire): agro-ecosystem R2

\begin{tabular}{|c|c|c|c|c|c|c|c|c|c|c|c|c|}
\hline & \multicolumn{6}{|c|}{ S. haematobium } & \multicolumn{6}{|c|}{ S. mansoni } \\
\hline & $\mathrm{N}$ & Prev. $(\%)$ & OR & $95 \% \mathrm{CI}$ & LRT & $\mathrm{P}$ & $\mathrm{N}$ & Prev. $(\%)$ & OR & $95 \% \mathrm{CI}$ & LRT & $\mathrm{P}$ \\
\hline $\mathrm{F}$ & 108 & 3.2 & 1 & & & & 108 & 15.5 & 1 & & & \\
\hline SEX M & 112 & 6.8 & 2.2 & $0.87-5.71$ & 2.98 & 0.084 & 112 & 13.2 & $0.73 c$ & $0.41-1.31$ & 1.13 & 0.2873 \\
\hline $4-7$ years & 89 & 1.8 & 1 & & & & 89 & 10.9 & 1 & & & \\
\hline AGE 8-11 years & 91 & 4.6 & 2.6 & $0.79-8.70$ & 7.34 & & 91 & 10.9 & 0.97 & $0.50-1.88$ & 2.7 & 0.2590 \\
\hline \multirow[t]{2}{*}{$12-15$ years } & 40 & 3.6 & 5.3 & $1.50-18.84 *$ & & $0.0254^{*}$ & 40 & 7.3 & 1.810 & $0.82-3.97$ & & \\
\hline & 220 & 10 & & & & & 220 & 29.1 & & & & \\
\hline \multicolumn{7}{|c|}{$\mathrm{R} 2=$ Two annual crops ; $\quad \mathrm{N}=$ Total number of individuals examined; } & \multicolumn{4}{|c|}{ Prev. $(\%)=$ Prevalence $(\%) ;$} & & \\
\hline OR= Odd Ratio; & \multicolumn{4}{|c|}{$\mathrm{CI}=$ Confidence interval; } & \multicolumn{4}{|c|}{ LRT = kke lihood ratio Test; } & \multicolumn{2}{|c|}{$\mathrm{P}=\mathrm{P}$ value; } & & \\
\hline \multicolumn{8}{|c|}{ Egg load = Geometric mean egg count of infected individuals per agro-ecosystem; } & & \multicolumn{2}{|c|}{$\mathrm{RR}=$ Risk Ratio } & & \\
\hline$*=$ Significant & & & & & & & & & & & & \\
\hline
\end{tabular}

Table 2: Negative binomial model to assess association between egg intensity with age and sex in Kafiné (Niakaramandougou, Côte d'Ivoire): agro-ecosystem R2

\begin{tabular}{|c|c|c|c|c|c|c|c|c|c|c|c|c|}
\hline & \multicolumn{6}{|c|}{ S. haematobium eggs load } & \multicolumn{6}{|c|}{ S. mansoni eggs load } \\
\hline & $\mathrm{N}$ & Eggs & $\mathrm{RR}$ & $95 \% \mathrm{CI}$ & LRT & $\mathrm{P}$ & $\mathrm{N}$ & Eggs & $\mathrm{RR}$ & $95 \% \mathrm{CI}$ & LRT & $\mathrm{P}$ \\
\hline $\mathrm{F}$ & 108 & 1.1 & 1 & & & & 108 & 3.4 & 1 & & & \\
\hline SEX M & 112 & 1.5 & 2.2 & $0.91-5.42$ & 3.04 & 0.0814 & 112 & 2.8 & 0.63 & $0.43-0.93 *$ & 5.53 & $0.0187 \%$ \\
\hline 4-7 years & 89 & 1.1 & 1 & & & & 89 & 2.9 & 1 & & & \\
\hline AGE 8-11 years & 91 & 1.3 & 2.6 & $0.80-8.17$ & 7.97 & & 91 & 2.7 & 0.78 & $0.50-1.21$ & 2.40 & \\
\hline \multirow[t]{2}{*}{$12-15$ years } & 40 & 1.9 & 5.2 & $1.56-17.24 *$ & & $0.0186^{*}$ & 40 & 4.6 & 1.12 & $0.70-1.80$ & & 0.3017 \\
\hline & 220 & 1.3 & & & & & 220 & 3.1 & & & & \\
\hline \multicolumn{7}{|c|}{ R2 = Two annual crops ; $\quad N=$ Total number of individuals examined; } & \multicolumn{4}{|c|}{ Prev. $(\%)=$ Prevalence (\%); } & & \\
\hline OR=0dd Ratio; & \multicolumn{4}{|c|}{$\mathrm{CI}=$ Confidence interval; } & \multicolumn{4}{|c|}{ LRT = lke lihood ratio Test; } & \multicolumn{2}{|c|}{$\mathrm{P}=\mathrm{P}$ value; } & & \\
\hline \multicolumn{8}{|c|}{ Egg load = Geometric mean egg count of infected individuals per agro-ecosystem; } & & \multicolumn{2}{|c|}{ RR $=$ Risk Ratio } & & \\
\hline * = Significant & & & & & & & & & & & & \\
\hline
\end{tabular}


Table 3: Logistic regression model with random effect to account association between Schistosoma mansoni infection and negative binomial model to assess association between egg intensity with age and sex in Pékaha (Niakaramandougou, Côte d'Ivoire): agro-ecosystem R0

\begin{tabular}{|c|c|c|c|c|c|c|c|c|c|c|c|c|c|}
\hline & & \multicolumn{6}{|c|}{ Prevalence of infection } & \multicolumn{6}{|c|}{ Eggs load } \\
\hline & & $\mathrm{N}$ & Prev.(\%) & OR & $95 \% \mathrm{CI}$ & LRT & $\mathrm{P}$ & $\mathrm{N}$ & Eggs & RR & $95 \% \mathrm{CI}$ & LRT & $\mathrm{P}$ \\
\hline & $\mathrm{F}$ & 57 & 18.1 & 1 & & & & 57 & 5.3 & 1 & & & \\
\hline \multirow[t]{2}{*}{ SEX } & M & 76 & 13.5 & 0.43 & $0.20-0.90 *$ & 5.09 & $0.0240 *$ & 76 & 2.5 & 0.4 & $0.25-0.77 *$ & 4.78 & $0.0287 *$ \\
\hline & 4-7 years & 42 & 12.8 & 1 & & & & 42 & 4.8 & 1 & & & \\
\hline \multirow[t]{3}{*}{ AGE } & $8-11$ years & 49 & 9 & 0.5 & $0.20-1.17$ & 2.68 & 0.2624 & 49 & 2.6 & 0.6 & $0.31-1.29$ & 4.12 & 0. \\
\hline & $12-15$ years & 42 & 9.8 & 1.7 & $0.27-1.62$ & & & 42 & 3.6 & 0.7 & $0.33-1.44$ & & 1275 \\
\hline & & 133 & 31.6 & & & & & 133 & 3.5 & & & & \\
\hline \multicolumn{3}{|c|}{ R2 = Two annual crops ; } & \multicolumn{5}{|c|}{$\mathrm{N}=$ Total number of individuals examined; } & \multicolumn{5}{|c|}{ Prev. $(\%)=$ Prevalence $(\%)$} & \\
\hline \multicolumn{2}{|c|}{ OR = Odd Ratio } & \multicolumn{4}{|c|}{$\mathrm{CI}=$ Confidence interval; } & \multicolumn{4}{|c|}{ LRT $=$ lke lihood ratio Test; } & \multicolumn{2}{|c|}{$\mathrm{P}=\mathrm{P}$ value } & & \\
\hline \multicolumn{9}{|c|}{ Egg load = Geometric mean egg count of infected individuals per agro-ecosystem; } & & \multicolumn{2}{|c|}{$\mathrm{RR}=$ Risk Ratio } & & \\
\hline \multicolumn{2}{|c|}{$*=$ Significant } & & & & & & & & & & & & \\
\hline
\end{tabular}

Table 4: Geohelminthiasis among school-age children in agro-ecosystems of Niakaramandougou, Côte d'Ivoire

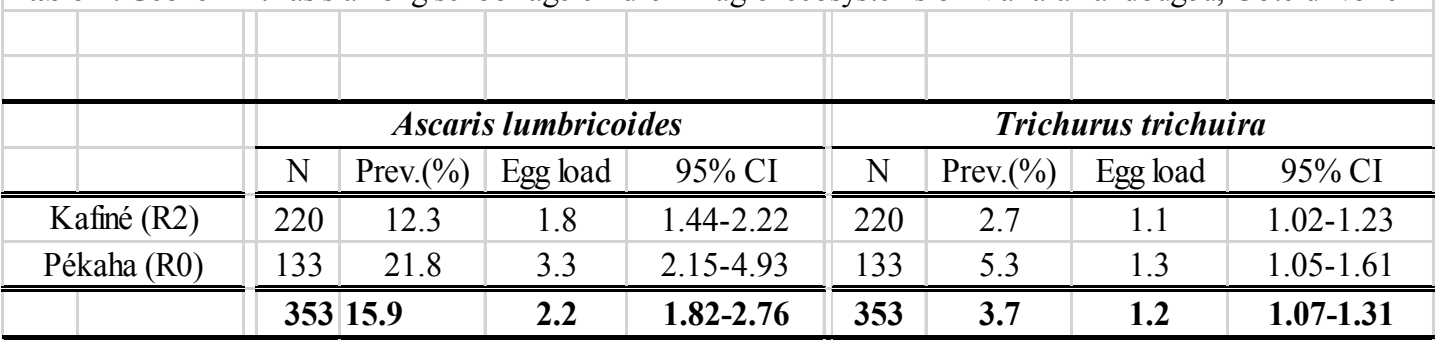

\begin{tabular}{l|l|l}
$\mathrm{R} 2=$ Two annual crops ; & $\mathrm{R} 0=$ No inland valley cultivation; & $\mathrm{N}=$ Total number of individuals examined;
\end{tabular} Prev.(\%) = Prevalence (\%); Egg load = Geometric mean egg count of infected individuals per agro-ecosystem; $\mathrm{CI}=$ Confidence interval

Table 5: Logistic regression model with random effect to account association between schistosomiasis infection with age and sex in agro-ecosystems of Niakaramandougou, Côte d'Ivoire

\begin{tabular}{|c|c|c|c|c|c|c|c|c|c|c|c|c|}
\hline & \multicolumn{6}{|c|}{ S. haematobium } & \multicolumn{6}{|c|}{ S. mansoni } \\
\hline & $\mathrm{N}$ & Prev. $(\%)$ & OR & $95 \% \mathrm{CI}$ & LRT & $\mathrm{P}$ & $\mathrm{N}$ & Prev.(\%) & OR & $95 \% \mathrm{CI}$ & LRT & $\mathrm{P}$ \\
\hline Kafiné (R2) & 220 & 10 & 1 & & & & 220 & 29.1 & 1 & & & \\
\hline Pékaha (R0) & 133 & 2.3 & 0.2 & $0.06-0.71$ & 4.43 & $0.0354 *$ & 133 & 31.1 & 1.1 & $0.71-1.80$ & 0.24 & 0.6218 \\
\hline & 353 & 7.1 & & & & & 353 & 30 & & & & \\
\hline \multirow{2}{*}{\multicolumn{2}{|c|}{ R2 = Two annual crops ; }} & \multicolumn{4}{|c|}{ R0 = No inland valley cultivation; } & & \multicolumn{6}{|c|}{$\mathrm{N}=$ Total number of individuals examined; } \\
\hline & & & & $\mathrm{OR}=\mathrm{Odd} \mathrm{Ra}$ & latio; & & \multicolumn{6}{|c|}{$\mathrm{CI}=$ Confidence interval; $\mathrm{LRT}=\mathrm{kke}$ lihood ratio Test; } \\
\hline \multicolumn{13}{|c|}{\begin{tabular}{|l|l|l|l|} 
Egg load = Geometric mean egg count of infected individuals per agro-ecosystem; & & \\
\end{tabular}} \\
\hline $\mathrm{P}=\mathrm{P}$ value; & \multicolumn{2}{|c|}{ * = Significant } & & & & & & & & & & \\
\hline
\end{tabular}




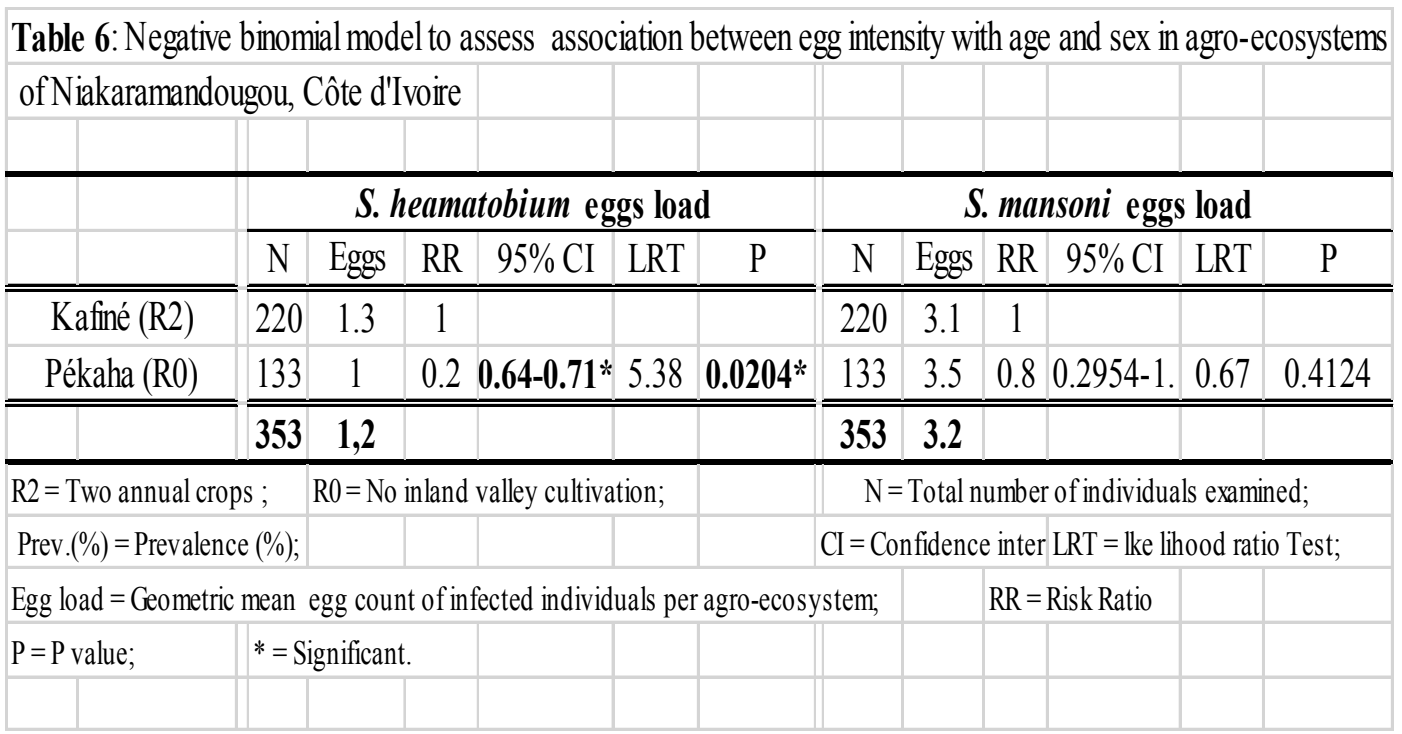

\section{DISCUSSION}

Impact of irrigated rice on the transmission of schistosomiasis and geohelmintiasis

Urinary schistosomiasis

Our results showed that the study villages were hypo-endemic areas. The data obtained also showed that the prevalence and intensity of infection were higher in Kafiné rice irrigated area than in Pékaha non-irrigated area. The permanence of water (regular contact man-water) and the existence of natural habitats throughout the year are important factors affecting the transmission of S. haematobium in Kafiné contrary to Pékaha, where water sources are dry six months in the year. The reported data showed that irrigated rice had an impact on the transmission of $S$. haematobium in the rice perimeter of Kafiné. Yapi et al. (2005) have recently shown that irrigated rice cultivation affects the transmission of $S$. mansoni in the savannah. It is obvious that the development of water resources including irrigation systems was partly responsible for the intensification of agricultural production. It is also obvious that using irrigation system increases opportunities of schistosomiasis transmission, as this brings about large surfaces of water and therefore, a large number of contact points. That situation was observed by several authors (Chitsulo et al., 2000; Steinmann et al., 2006). These authors reported that the prevalence and parasite loads in West Africa are generally high in irrigated areas (Coulibly et al., 2004; Poda et al., 2006). Similar results have been reported in Senegal (Southgate et al., 2001), in Nigeria (Ofoezi, 2002), in Ghana (Hunter and More, 2003) and in Côte d'Ivoire (Diakité et al., 2017). The importance of schistosomiasis infection in a community can be assessed by the intensity of the elimination of eggs. The low egg load observed indicate the nonseverity of $S$. heamatobium infection.

\section{Intestinal schistosomiasis}

Schistosomiasis infection level indicates that Kafiné and Pékaha are hypoendemic areas of S. mansoni. The analysis of infection by gender showed notable absence of infestation difference between boys and girls in R2. This fact could be explained by the similar contacts with the sources of contamination. In R0, girls are more affected than males. This difference of infestation could be due to the sharing of daily tasks. The girls would be expected to help their mothers in the work of laundry, dishes and fetching water which are important risk factors. The Analysis of the results of infection by age revealed no significant difference in age groups. This observation allows us to state 
that the R2 village is a recent endemic zone $S$. mansoni, if one refers to the work of Dabo et al. (2003). they argues that it is commonly known that in cases of a recent implantation of schistosomiasis, the differences in prevalence between age groups are very low or zero, while Diakité et al. (2017) indicated that differences in infection between ages will be more significant if the transmission is intense. The geometric average parasite loads reported, although low in both villages (3.1 eggs/g stool in R2 and 3.5 eggs/g stool in R0) remains higher than those reported by Coulibaly et al. (2004), Yapi et al. (2005) were 1.9 and 1.1 eggs/g of faeces respectively in R2 and R0 at Korhogo. The ovular transmission is higher among girls than boys in both agro-ecosystems. Zongo et al. (2012), Yapi et al. (2014) reported a difference in prevalence by gender in Sahel with a higher infection in men than women. Socioanthropological surveys would provide clarification on the behavior of both sexes in contamination sources. The low ovular loads noted in R0 and R2 for intestinal schistosomiasis could be considered an asset that can facilitate the control of the disease through the implementation of a short-term action plan for the fight.

The results revealed absence of link between the prevalence and intensity of $S$. mansoni and the presence of irrigated rice. This non-attendance of link has been described in the Economic Community of West African States (ECOWAS) (Mali, Niger, Burkina Faso, Benin, Cape Verde, Côte d'Ivoire, Gambia, Ghana, Guinea, Guinea Bissau, Liberia, Senegal, Sierra Leone, Nigeria, Togo (Cunin et al., 2000; Audibert and Mathonnat, 2001; Moné et al., 2010; Wallet et al., 2016). Many parts of West African States have been a constant in the prevalence of malaria and schistosomiasis after six years of practice rice. This crosssectional survey has noted that irrigated rice was not the main factor in the transmission of schistosomiasis in the study area. The distance of the study sites in relation to water contacts, the extent of the rice-growing area, would be potential risk factors (Yapi et al., 2005). In order to have a better assessment of the effect of rice on the health status of the populations, it would be desirable to combine the molluscan studies over a period of at least one year, socio-anthropological studies, and longitudinal parasitological studies in other villages provided with irrigated and nonirrigated lowlands.

\section{Geohelminths prevalence}

The ascariasis and trichuriasis were the only helminths observed. Their prevalence and eggs load are relatively high in rice irrigated area (Agro-ecosystem R2) as nonrice irrigated lowland (Agro-ecosystem R0). In consideration of the benign nature of trichuriasis, our comments focused primarily on ascariasis whose consequences are large. The ascariasis affects mostly children of school age (5-15 years) by disrupting the growth of the child (Tetteh, 2012; Ibikounlé et al., 2013). Low prevalence of ascariasis has been reported in Mali $(0.1 \%)$ by Dabo et al. (2003), in Ethiopia (17.8\%) by Worku et al., (2009), in Côte d'Ivoire (17.2\%) by Yapi et al. (2016). High prevalence of $A$. lumbricoides has been reported) in Mali (78\%) by Dold and Holand (2010). Our results were comparable to those reported in Nigeria $(30.7 \%)$ by Auta et al. (2013), in Côte d'Ivoire (24.7\%) by Matthys et al. (2007). Ascariasis prevalence depends largely on personal hygiene and behaviour (interaction with the environment) (Plate et al., 2004), but also on the parasite itself (e.g. immaturity, male predominance, low infestation or low fertility).

Current studies do not allow linking the role of reservoir hosts to human transmission. Pigs host the parasite and can be considered as a sure source of contamination to humans (Crompton, 2001). Environmental factors including the structure and the composition of the soil and climatic factors should be expected to influence the distribution and prevalence of Ascaris lumbricoides and others worms (Trichuris, Strongyloides and Oxyurus) because of their role in embryonation and in the survival of 
infective eggs. In Africa, A. lumbricoides prevalence is generally low in arid climate zones (savanna) and high in those with consistent wet weather and warmth (forest). Our observations were confirmed by Hotez (2000) in Cameroon and Yapi et al. (2006) in Côte d'Ivoire.

The effect of these helminthiases on health is not negligible, especially in children and when malnutrition also occurs. Effective control of these helminthiases, education and economic development must be promoted, but the present situation of the economy in most developing countries such as Côte d'Ivoire is far from considering the fight against geohelminthic diseases as a priority.

\section{Conclusion}

Studies conducted in the agroecosystems R2 and R0, in the savannah of Niakaramandougou, Ivory Coast showed a non-association infection of S. mansoni and irrigated rice production on the one hand, and on the other hand, a strong correlation between infection with $S$. haematobium and irrigated rice. The low eggs loads would be militate of limited transmission. The absence of difference in infection by age groups showed that we were in the process of recent establishment of schistosomiasis in the study villages.

In the savannah, intestinal schistosomiasis was significantly prevalent in the agro-ecosystems R2 and R0. Intensity of infection was related to the amount of rice cultivation and not to the amount of naturally occurring surface water. Our study has shown the link between irrigation and $S$. heamtobium in medium scale irrigation.

It is important to stress that rice cultivation itself does not constitute the main factor of schistosomiasis. Recreational and toilet behaviours of children play an important role, as shown by the significance of the risk factor distance to the closest inland valley. Further assessments of the impact of rice irrigation and similar agricultural practices on prevalence and morbidity from human schistosomiasis would be helpful in reaching informed decisions regarding the widespread implementation of this cultivation method. In conjunction with information on snail vectors and the frequency of water contact, longitudinal studies of schistosomiasis in some villages with and without rice irrigation might permit better appreciation of the effect of inland valley farming on these aspects of infection.

\section{COMPETING INTERESTS}

The authors declare that there is no conflict of interest regarding the publication of this paper.

\section{ACKNOWLEDGEMENTS}

The Funding of this study was provided by the Veterinary and Medical Entomology Centre (CEMV) and the Government of Senegal. We would like to express our gratitude to the populations of Kafiné and Pékaha villages for their contribution to this research, and to $\mathrm{Mr}$. OKPO Drama, Inspector General for National Education and Technical Training, Côte d'Ivoire, for his useful corrections of this article.

\section{REFERENCES}

Audibert M, Mathonnat J, Bokossa MJ, Diabagate A. 2001. Systèmes de production rizicole et maladies parasitaires dans l'Afrique de l'Ouest : caractéristiques socio-économiques des ménages agricoles en zone de forêt ivoirienne. CERDI, Etudes et Documents, 30P

Auta T, Kogi E, Audu OK, 2013. Studies on the Intestinal Helminths Infestation among Primary School Children in Gwagwada, Kaduna, North Western Nigeria. Journal of Biology, Agriculture and Healthcare, 3(7): 48-53.

Barboza DM, Zhang C, Santos NC, Silva MMBL, Rollemberg CVV, Amorim FJR, Ueta MT, Melo CM, Almeida JAP, Jeraldo VLS, Jesus AR, 2012. 
Biomphalaria species distribution and its effect on human Schistosoma mansoni infection in an irrigated area used for rice cultivation in northeast Brazil. Geospatial Health, 6(3): S103-S109.

Bouguerra L, 2001. Hydro-aménagements et bilharzioses : le lit de la maladie. Colloque international «Eau et Santé "Science au Sud, $\mathrm{n}^{\circ}$ 11,3p Chang LY, 2005. Analysis of freeway accident frequencies: Negative binomial regression versus artificial neural network. Safety Science, 43(8): 541-557.

Chitsulo L, Engels D, Montresor A, Savioli L, 2000. The global status of schistosomiasis and its control. Acta Tropica, 77(1): 41-51.

Coulibaly G, Diallo M, Madsen H, Dabo A, Traoré M, Keita S, 2004. Comparison of schistosome transmission in a single- and a double-cropped area in the rice irrigation scheme, 'Office du Niger', Mali. Acta Tropica, 91: 15-25.

Crompton DWT, 2001. Ascaris and ascariasis. Advances in parasitology, 48: 285-375 Cunin P, Griffet A, Poste B, Djibrilla K, Martin PMV. 2000. Epidemic Schistosoma mansoni in a known $S$. haematobium area. Transactions of the Royal Society of Tropical Medicine and Hygiene, 94(6): 657-660.

Dabo A, Sow MY, Sangaré L, Maiga I, Keita A, Bagayoko Y, Kouriba B, Doumbo O. 2003. Transmission of schistosomiasis in an urban population and prevalence of intestinal helminthiasis in Bamako, Mali. Bulletin de la Société de Pathologie Exotique, 96(3): 187-190.

Diakité NR, Winkler MS, Coulibaly JT, Guindo-Coulibaly N, Utzinger J, N'Goran EK. 2017. Dynamics of freshwater snails and Schistosoma infection prevalence in schoolchildren during the construction and operation of a multipurpose dam in central Côte
d'Ivoire. Infectious Diseases of Poverty, 6: 93 . DOI 10.1186/s40249-017-0305-3

Diallo SM. 1996. Contribution à l'étude de la valeur diagnostique des méthodes de présomption dans le dépistage de masse des Schistosomoses en milieu rural de Côte d'Ivoire. Mém. DEA, Université d'Abidjan-Cocody, 90.

Diouf S, Diallo A, Camara B, Diagne I, Tall A, Signate HS, Moreira C, Sall MG, Sarr M, Fall M, 2000. La malnutrition protéino-calorique chez les enfants de moins de 5 ans en zone rurale sénegalaise (Khombole). Médecine d'Afrique Noire, 47(5) : 225-228.

Dold C, Holland CV, 2010. Ascaris and ascariasis. Microbes and Infection, 13(7) : 632-637.

Gryseels B, Polman K, Clerinx J, Kestens L, 2006. Review Human schistosomiasis. Lancet, 368(9541):1106-1118.

Hotez PJ, 2000. Pediatric geohelminth infections: Trichuriasis, ascariasis, and hookworm infections. Seminars in Pediatric Infectious Diseases, 11(4): 236-244.

Hunter JM, More S, 2003. Inherited burden of disease: agricultural dams and the persistence of bloody urine (Schistosomiasis hematobium) in the Upper East Region of Ghana, 19591997. Social Science \& Medicine, 56(2): 219-234.

Ibikounlé M, Satoguina J, Fachinan R, Tokplonou L, Batcho W, Kindé-Gazard D, Mouahid D, Moné H, Massougbodji A, Courtin D. 2013. Épidémiologie de la bilharziose urinaire et des geohelminthiases chez les jeunes scolaires des zones lacustres de la commune de So-Ava, sud-Bénin. Journal of Applied Biosciences, 70: $5632-5639$.

Matthys B, Tschannen AB, Tian-Bi NT, Comoé $\mathrm{H}$, Diabaté $\mathrm{S}$, Traoré $\mathrm{M}$, 
Vounatsou P, Raso G, Gosoniu L, Tanner M, Cissé G, N'Goran EK, Utzinger J. 2007. Risk factors for Schistosoma mansoni and hookworm in urban farming communities in western Côte d'Ivoire. Tropical Medicine \& International Health, 12(6): 709-723.

Minami M, Lennert-Cody CE, Gao W, Román-Verdesoto M. 2007. Modeling shark bycatch: The zero-inflated negative binomial regression model with smoothing. Fisheries Research, 84(2): 210-221.

Mitchell S, Pagano M. 2012. Pooled Testing for Effective Estimation of the Prevalence of Schistosoma mansoni. Am J Trop Med Hyg, 87(5): 850-861.

Moné H, Ibikounlé M, Massougbodji A, Mouahid G. 2010. Human Schistosomiasis in the Economic Community of West African States: Epidemiology and Control. Advances in Parasitology, 71: 33-91.

Ofoezie IE, 2002. Human health and sustainable water resources development in Nigeria: Schistosomiasis inartificial lakes. Natural Resources Forum, 26(2): 150-160.

Plate DK, Strassmann BI, Wilson ML. 2004. Water sources are associated with childhood diarrhoea prevalence in rural east-central Mali. Tropical Medicine and International Health, 9(3): 416-425.

Poda JN, Mwanga J, Dianou D, Garba A, Ouédraogo FC, Zongo D, Sondo KB, 2006. Les parasitoses qui minent les nouveaux pôles de développement au Burkina Faso : cas des schistosomoses et des géohelminthes dans le complexe hydroagricole du Sourou. L'Afrique face au développement durable, VertigO - La Revue Electronique en Sciences de l'Environnement, 7(21): DOI: $10.4000 /$ vertigo. 2378
Ridout M, Hinde J, DemBtrio CGB, 2001. A Score test for testing a zero-inflated poisson regression model against zeroinflated negative binomial alternatives. Biometrics, 57: 219-223. Doi:10.1111/j.0006-341X.2001.00219.x Scolari C, Torti C, Beltrame A, Matteelli A, Castelli F, Gulletta M, Ribas M, Morana S, Urbani C. 2000. Prevalence and distribution of soil-transmitted helminth (STH) infections in urban and indigenous schoolchildren in Ortigueira, State of Paranà, Brasil: implications for control. Tropical Medicine \& International Health, 5(4): 302-307.

Southgate VR, Tchuem Tchuenté LA, Sène M, De Clercq D, Théro A, Jourdane J, Webster BL, Rollinson D, Gryseels B Vercruysse J. 2001. Studies on the Biology of Schistosomiasis with Emphasis on the Senegal River Basin. Mem. Inst. Oswaldo Cruz, 96: 75-78.

Steinman P, Keiser J, Bos R, Tanner M, Utzinger J. 2006. Schistosomiasis and water resources development: systematic review, meta-analysis, and estimates of people at risk. The Lance Infectious Diseases, 6(7): 411-425.

Sturrock RF, Diaw OT, Talla I, Niang M. 2001. Seasonality in the transmission of schistosomiasis and in populations of its snail intermediate hosts in and around a sugar irrigation scheme at Richard Toll, Senegal. Parasitology, 123(7): 77-89.

Tandina F, Doumbo SN, Kone' AK, Guindo D, Goita S, Sissoko M, Konate' S, Dabo A, Doumbo OKQ. 2016. Épidémiologie des schistosomoses dans le village périurbain de Sotuba, dix années après la mise à échelle du traitement de masse au Mali. Médecine et Santé Tropicales, 26(1): 1-6.

Tetteth P. 2012. A comparative study of intestinal parasitic infection and associated risk factors among primary 
school children in six neighbouring communities in Kumasi, Ghana: Ayigya, Kentinkrono, Aboabo, Manhyia, Gyinyase and Kyirapatre. Thesis, Kwame Nkrumah University of Science and Technology, Kumasi, Ghana, 187p

Tchuem- Tchuenté LA. 2006. Lutte contre la schistosomose : défi et perspectives pour le XXIe siècle. Bull. Soc. Pathol. Exot., 99(5): 372-376le.

Wallet F, Sicard D, Brey P, Lambrozo J. 2016. Impacts sanitaires des barrages : les leçons d'une étude de cas. Environnement, Risques \& Santé, 15(5) : 419-425

Worku N, Erko B, Torben W, Belay M, Kasssu A, Fetene T, Huruy K. 2009. Malnutrition and intestinal parasitic infections in school children of Gondar, North West Ethiopia. Ethiopian Medical Journal, 47(1): 9-16.

Yapi BR, Chamartin F, Hürlimann E, Houngbedji CA, N'DRI PB, Silué KD, Utzinger J, N'Goran KE, Vounatsou P, Raso G. 2016. Bayesian risk profiling of soil-transmitted helminth infections and estimates of preventive chemiotherapy for school-aged children in Côte d'Ivoire. Parasites and Vectors: 9-196.
Yapi BR, Chamartin F, Hürlimann E, Houngbedji CA, N'DRI PB, Silué KD, Soro G, Kouamé FN, Vounatsou P, Fürst T, N'Goran K E, Utzinger J, Raso G. 2014. Infection and co-infection with helminth and plasmodium amo,g school children in Côte d'Ivoire : résults from a national cross-sectional survey. PLOS Negleted Tropical Diseases, 8(6): e291327.

Yapi YG. 2008. Endémie schistosomienne en zones de savane et de forêt montagneuse de Côte d'Ivoire. Thèse de Doctorat d'Etat, Université Félix Houphouet Boigny, N572, 200p.

Yapi YG, Briët OJT, Diabate S, Vounatsou P, Akodo E, Tanner M, Teuscher T. 2005. Rice irrigation and schistosomiasis in savannah and forest areas of Cote d'Ivoire. Acta Tropica, 93: 201-211.

Yapi YG, Briët OJT, Vounatsou P. 2006. Prevalence of geohelminths in savanna and forest areas of Côte d'Ivoire. West Afr. J. Med., 25(2): 124-125.

Zongo D, Kabre BG, Dayeri D, Savadogo B, Poda JN. 2012. Étude comparative de la transmission de la schistosomiase (formes urinaire et intestinale) dans dix sites du Burkina Faso. Médecine et Santé Tropicales, 22: 323-329. 